\title{
Settler-Humanitarianism: Healing the Indigenous Child-Victim
}

\author{
KRISTA MAXWELL \\ Anthropology, University of Toronto
}

IN T R O DUCTION

\section{Healing "Native Anguish and Discontent"}

In a program televised in October 1990, veteran Canadian Broadcasting Corporation reporter Barbara Frum interviewed Chief Phil Fontaine about his childhood experiences of sexual abuse at Fort Alexander Catholic residential school. ${ }^{1}$ Before she commenced, Frum made a curious reference to the previous summer's military and political conflict between First Nations and the Canadian settler-state. Speaking directly to viewers through the camera, she earnestly pronounced, "This summer's standoff at Oka has heightened public interest in the source of Native anguish and discontent."

By "standoff at Oka," Frum was referring to Kanehsatake Mohawks' occupation of the site of an ancient cemetery on their territory that was threatened by a golf course expansion planned by the town of Oka. First Quebec provincial police, then Canadian military, tried to forcibly remove the protestors. Led by women and supported by the Mohawk Warrior Society, the occupation attracted unprecedented international media attention, becoming a symbol of both solidarity and resistance for Indigenous peoples and a focal point for settler racism and violence (Orsini 2010; Valaskakis 2005; Wagamese 1996).

\footnotetext{
Acknowledgments: The ideas expressed here have benefitted enormously from my engagement with multiple teachers, colleagues, and other interlocutors over many years, and I am deeply grateful to all. I particularly appreciate Andrea Muehlebach's and Arie Molema's constructive comments on multiple drafts of this paper, Joseph P. Gone for his encouragement to attend to "shades of gray" and the pragmatics of positive interventions in Native communities, and two rounds of CSSH reviewers for extensive and extremely helpful feedback. This research was supported by doctoral and postdoctoral funding from the Social Sciences and Humanities Research Council of Canada and the Network for Aboriginal Mental Health Research.

${ }^{1}$ Fontaine was one of the first Indigenous political leaders to speak publicly about his residential school experiences. Previously Chief of Sagkeeng First Nation, in 1991 he was elected Grand Chief of the Assembly of Manitoba Chiefs, serving three terms.
} 
Frum's identification of "anguish and discontent" as dominant affective registers characterizing the Kanehsatake resistance is a noteworthy reinterpretation of the Mohawks' calm determination and articulate expressions of anger that were palpable in documentation of the event. ${ }^{2}$ Frum's suggestion that her interview with Fontaine would reveal the hitherto unknown "source" of Indigenous "anguish and discontent" implied that the Canadian public could or would not understand the Kanehsatake occupation as a straightforward, legitimate response to violent dispossession. Indigenous peoples' profound attachments to place, which encompass social, spiritual, legal, and governance systems that flow from territory (Borrows 2002), are not readily grasped by most Canadians, who remain largely unfamiliar with Indigenous ontologies.

Frum's reframing and reattribution of Indigenous affect seemed intended to reshape viewers' own affective responses, from confusion and contempt toward the righteous, angry Mohawk warrior into sympathy for the innocent, Indigenous child-victim, ${ }^{3}$ and Fontaine's account centered on this latter, emergent figure. ${ }^{4} \mathrm{He}$ described long-term, pernicious effects suffered by those who had been sexually abused at the Fort Alexander school, implying that such past experiences directly contributed to pervasive, ongoing abuse and trauma in contemporary Indigenous communities. ${ }^{5}$ Fontaine's interview launched a discourse on former students of the Indian residential schools as dysfunctional victims of past abuse, and this became the fulcrum for "Aboriginal healing" in the present. In his concluding comments, he called for "a healing process, to make our people whole, so that when we talk about the future, that we can talk ... as whole people and not as a people that has ... many, many individuals with missing parts and pieces and gaps in their being." Subsequently, as Grand Chief of the Assembly of First Nations for three terms (1997-2000, 2003-2009), Fontaine led negotiations with the federal government leading to the 2006 Indian Residential Schools Settlement Agreement (hereafter the "Settlement Agreement"), the terms of which ultimately defined "healing" in public discourse.

Nearly two decades after Frum interviewed Fontaine, on 11 June 2008, Canadian Prime Minister Stephen Harper delivered an apology for Indian residential schools in which he publicly established the settler-state's role in facilitating "healing" of their former students. ${ }^{6}$ Harper's invocation of "healing" is, I

${ }^{2}$ See, for example, Obomsawin 1993.

${ }^{3}$ I thank Arie Molema for suggesting this perspective.

${ }^{4}$ At http://www.cbc.ca/archives/entry/phil-fontaines-shocking-testimony-of-sexual-abuse (last accessed 5 July 2016).

5 In Fontaine's own words, it produced "distortion of (the victim's) sense of morality"; "the abused becomes the abuser [...] acting out what has been done to you."

${ }^{6}$ Harper's was the most famous of several apologies delivered by representatives of successive Canadian governments. The first was by Minister Stewart as part of the Gathering Strength statement discussed later in this paper. The full text of Harper's apology is at https://www.aadnc-aandc. gc.ca/eng/1100100015644/1100100015649 (accessed 22 Apr. 2017). 
argue, exemplary of settler-humanitarianism. Noting "tragic accounts of the emotional, physical, and sexual abuse and neglect of helpless children, and their separation from powerless families and communities," Harper concurred with Fontaine that "the legacy of Indian Residential Schools has contributed to social problems that continue to exist in many [Indigenous] communities today." Further, he claimed healing effects for his government's interventions, including financial compensation paid under the Settlement Agreement, and for his apology itself, noting, "The absence of an apology has been an impediment to healing and reconciliation."

In this paper, I analyze how both Indigenous leaders and settler-state agents have drawn on "humanitarian reason" to co-constitute Aboriginal healing as public policy (Fassin 2012; see also Million 2013). ${ }^{7}$ I use "settlerhumanitarianism" to emphasize how liberal interventions inspired by sympathy for Indigenous suffering are aligned with settler-colonialism's enduring goal of eliminating Indigenous peoples in order to control and exploit their territory (Wolfe 2006). ${ }^{8}$ Wolfe's formulation of Indigenous elimination as an "organizing principle" rather than an "event" directs us to analyze how settler-colonial political actors have adapted this principle across shifting historical and political contexts. Humanitarians condemned the mass killings that characterized eighteenth- and nineteenth-century colonialism in Australia and Canada, but urged liberal, humane forms of territorial dispossession instead (Lester and Dussart 2014). Settler-humanitarian interventions led, therefore, not to annihilation, but rather to new modes of governance that pursued the elimination of Indigenous peoples as distinct social and political entities. Humanitarian approaches to Indigenous elimination have been both uneven and contested and have ultimately failed (Simpson 2014).

The Indigenous child-victim provides the focal point for my comparative analysis of settler-humanitarianism across Canada and Australia, and the imperial and neoliberal periods. The figure of the abused and traumatized victim of the residential schools, centerpiece of Canadian Aboriginal healing policy, bears a family resemblance to the debased native child of the nineteenthcentury British colonies that was the target of "imperial humanitarianism" (Barnett 2011). ${ }^{9}$ Both the Indian residential school system in Canada and

\footnotetext{
${ }^{7}$ I mark as "Aboriginal" the policies, discourses, and practices associated with state-mediated healing in cognizance of Alfred and Corntassel's (2005) argument that state-authorized Aboriginality privileges the authority of the Canadian state in defining Indigenous peoples' political and legal entitlements, displacing Indigenous social, cultural, and geopolitical identifications.

${ }^{8}$ I am indebted to Michael Barnett's (2011) analysis of humanitarianism as a trans-historical, trans-border phenomenon, and have adapted his definition to the settler-colonial context. Barnett defines humanitarianism by three main elements: "assistance beyond borders, a belief that such transnational action [is] related in some way to the transcendent, and the growing organization and governance of activities designed to protect and improve humanity" (ibid.: 10).

9 I am adapting Barnett's (2011) periodization, which locates "imperial humanitarianism" from the late eighteenth century to the Second World War.
} 
Australia's child-removal interventions that created the "Stolen Generation" were imperial settler-humanitarian projects focused on removing, containing, and rehabilitating Indigenous children. ${ }^{10}$ Recognizing contemporary Aboriginal healing as settler-humanitarianism foregrounds this irony, and underscores the need for critical, historicized analyses of continuities and discontinuities between past and present settler-state projects of Indigenous child-rescue.

That such analyses are required is well-illustrated by the recent report of Canada's Truth and Reconciliation Commission (2015). ${ }^{11}$ Although this report's wide-ranging "Calls to Action" prioritize addressing the overrepresentation of Indigenous children in the contemporary child welfare system, it fails to critically analyze how and why child-removal remains central to relations between the settler-state and Indigenous peoples. The authors begin by describing the residential schools as "cultural genocide," defined as "the destruction of those structures and practices that allow the group to continue as a group" (ibid.: 1). But, crucially, they do not extend this line of analysis to the removal of Indigenous children in the present. ${ }^{12}$ This is a striking disconnect, given that Indigenous peoples' continuation as groups remains threatened in these same terms, specifically by contemporary "structures and practices" that undermine kinship (Blackstock 2008; de Leeuw, Greenwood, and Cameron 2010; Miskimmin 2007; Richardson and Nelson 2007). Instead, the Commission's report explains contemporary child apprehension as "a result or legacy of the way that Aboriginal children were treated in residential schools" (2015: 135). This etiology, central to Aboriginal healing, attributes the contemporary apprehension of Indigenous children to dysfunction inherent in Indigenous families rather than to an ideology inherent in settler-statecraft.

The concept of cultural genocide was also central to the report's Australian counterpart, the 1997 Human Rights and Equal Opportunity Commission's Bringing Them Home. This is perhaps unsurprising, given that clause (e), Article 2 of the UN Convention on Genocide specifically describes the forcible transfer of children between groups. But as van Krieken points out, though cultural genocide featured in an early draft of the Convention, it was ultimately excluded; clause (2e), its only remnant, "was retained because delegates argued that the transfer of children is, in fact, "physical genocide"" (2004: 136). He also argues that public debate regarding the applicability of "cultural genocide" in settler-colonial settings has become polarized because of the erroneous assumption that "welfare" and "genocide" are mutually exclusive

\footnotetext{
${ }^{10}$ I am grateful to an anonymous $C S S H$ reviewer of an earlier draft for this insight, now central to my analysis.

11 The Commission was established under the terms of the Settlement Agreement.

12 Niezen (2016) similarly notes this failure of the TRC to critically examine how contemporary Canadian institutions are continuous with the residential schools, a failure he attributes to a "victim centrism" that defined the TRC's mandate and operations.
} 
categories (ibid.: 139). ${ }^{13}$ Settler-humanitarianism disrupts this intransigence by challenging the normative opposition drawn between the destruction of Indigenous peoples and interventions meant to address their welfare. Indeed, imperial humanitarians innovated the link between the control and containment of Indigenous peoples and their "care" and "protection" (Lester and Dussart 2014).

Historicizing settler-humanitarianism is important, then, not as the basis for a post hoc defense of state-authorized child-removal, as has been the case in Australian public debate, but to enable rigorous analyses of how liberalism enables myriad forms of settler violence. ${ }^{14}$ This approach enables the recognition that Canadian residential schools policy orchestrated an uneven but genocidal "process of destruction" (Woolford 2014: 30). Moreover, it elucidates how Christian evangelists' moral commitment to rescuing and rehabilitating Indigenous children was foundational to how these institutions functioned. A properly historicized approach facilitates critical analysis of continuities between imperial projects of Indigenous child-rescue and rehabilitation and present-day, liberal interventions into Indigenous family life. This is important because some vociferous critics of the former misconstrue the latter as benevolent.

\section{Aboriginal Healing Policy, Native Healing Praxis, and Humanitarian Resurgence}

Harper's apology advanced an understanding of healing victims consistent with global reconciliation discourse, which stresses public reckoning over past wrongs, targeted therapeutic interventions, and financial reparations (Regan 2010; Sundar 2004). It also reinforced a racializing hierarchy of capable agents of the settler-state rehabilitating damaged Indigenous victims. But Indigenous healing was not always a settler-humanitarian project. I argue that the Aboriginal healing discourse I trace in this paper has origins in a very different model, one developed by Indigenous-led, anticolonial grassroots movements that spanned North America from the 1960s onward. I call this latter approach "Native healing praxis" (see also Jacob 2013). ${ }^{15}$

Social histories reveal a close relationship between Native healing praxis and anticolonial political activism during the 1970s and 1980s (Maxwell 2011).

13 On debate in the Canadian media, see, for example, (Akhavan 2016). Van Krieken's helpful analysis (2004) links recent Australian debate to longstanding tension between "narrow" versus "broad" definitions of genocide, traceable to Lemkin's original (1944) formulation and United Nations debates on the Genocide Convention.

${ }^{14}$ I thank an anonymous CSSH reviewer for pointing out the use of humanitarianism as a defense against accusations of cultural genocide in Australia.

${ }^{15}$ I use "Native" because it is preferred by many of my interlocutors and to emphasize the distinction from the domain of "Aboriginal" public policy. Of course, "Native" is an equally colonial term of identification. I am over-drawing the contrast somewhat for the sake of clarity of argument. 
At that time, proponents of Native healing explained social suffering in their communities as a result of past and present settler-colonial interventions, not always successful, aimed at dismembering Indigenous families. Similarly, ethnographic literature analyzing Indigenous healing in late twentieth-century North America describes shared understandings of colonization as etiological of social suffering in the present, bridging diverse, diffuse, and dynamic healing discourses and practices (Adelson 2000; Csordas 1999; Jacob 2013; Kirmayer and Valaskakis 2009; Kunitz and Levy 1997; Marshall 2011; Proulx 2003; Waldram 1997; 2008). Since the late 1970s, as champions of Native healing have increasingly sought public funding for programming, so linked discourses have morphed with other paradigms of suffering and recovery, ranging from Alcoholics Anonymous to popular psychology (Kunitz and Levy 1997; Maxwell 2011) and human development (Million 2013), most recently by incorporating the concept of "trauma" (Kirmayer, Gone, and Moses 2014; Maxwell 2014).

Anticipated by Phil Fontaine's 1990 public statement, historical trauma theory - the idea that past experiences of abuse, even by previous generations, can cause present dysfunction - is now ubiquitous, not only in discussions of residential schools but in broader public and professional discussions of Indigenous health and wellness. Native American health professionals originally developed this theory, drawing on scholarship addressing Holocaust survivors and their descendants (Kirmayer et al. 2014; Maxwell 2014). Canadian political actors have recently adopted historical trauma to redefine contemporary Indigenous social suffering as the psycho-social effects of the residential school system. Proponents argue that such effects are inter-generationally transmitted, and underlie myriad, contemporary health and social problems in Indigenous communities (Chansonneuve 2005; Wesley-Esquimaux and Smolewski 2004). The salience of historical trauma in Indigenous health discourse in Canada is, I argue, attributable in part to work by the Royal Commission on Aboriginal Peoples and the Aboriginal Healing Foundation. ${ }^{16}$ It is also part of the global rise since the 1990s of a humanitarianism characterized by concern for newly-emergent categories of victimhood (Fassin 2012; Fassin and Pandolfi 2010; Fassin and Rechtman 2009; Ticktin 2011).

In his CBC interview, Phil Fontaine's discourse heralded the shift toward humanitarianism's universalized representations of suffering, ventriloquizing but depoliticizing earlier Native healing discourse. In describing residential school experiences as etiological of dysfunction, Fontaine connected three categories of suffering indexical of contemporary understandings of humanity:

\footnotetext{
16 Widely circulated publications commissioned by the Aboriginal Healing Foundation, such as Wesley-Esquimaux and Smolewski 2004, and Chansonneuve 2005, were important in cementing the discursive link between residential schools and historical trauma among health professionals and political actors.
} 
childhood sexual abuse, trauma, and interpersonal violence (implicitly, sexual violence between adults). This narrow, universalizing formulation of the residential schools' impact risks obscuring, as did Frum's preface to the interview, how Indigenous suffering flows from more wide-ranging, collective experiences of colonization, characterized by the severing of attachments to territory, nation, community, and kin (see Chrisjohn and Young 2006). And Fontaine's framing, like Frum's, suggests a capitulation to liberal, settler-society's insistence on understanding the suffering of Indigenous peoples in familiar, paternalistic terms of individual victimhood. But Fontaine's also proved to be a tactical move that inspired significant policy developments, culminating in the 2006 Settlement Agreement.

In recent literature addressing this contemporary resurgence of humanitarianism (Fassin 2012; Fassin and Pandolfi 2010; Ticktin 2011), few accounts have attended to settler-colonial contexts (but see Howard-Wagner 2010). ${ }^{17}$ However, as I will discuss presently, recent historiography compellingly demonstrates how British settler-colonies were sites where humanitarian projects, genocidal relations, and colonial governmentality were entangled in complex ways (Edmonds and Johnston 2016; Lester and Dussart 2014; Rogers and Bain 2016). In what follows, I will bridge these literatures and contribute to critical analyses of how relations between Indigenous peoples and settler-states are shaped by historical continuities, in articulation with contemporary public cultures (Byrd 2011; Coulthard 2014; Henderson 2012; Million 2013; Molema 2016; Povinelli 2011; Simpson 2014; Stringer 2007).

I begin by showing how Indigenous child-rescue became instrumental to late nineteenth-century settler-state formation in Canada and Australia, and then regained political currency as part of neoliberal settler-statecraft in the 1990s. Imperial humanitarians legitimated "rescuing" Indigenous children from their own families and communities by denigrating parents as backward, claiming there would be moral and material benefits for the children and projecting that the latter's "remolding" would benefit the emergent settler-state and society. I attribute the late twentieth-century reappearance of settlerhumanitarianism to the simultaneity of the rise of the global Indigenous rights movement, which threatens settler-state and corporate interests in natural resource extraction from Indigenous territories, and the intensified social suffering of Indigenous families under neoliberal fiscal policies, which provides moral cover for humanitarian interventions.

In the paper's second half I return to the contemporary case of Aboriginal healing in Canada to examine how differently located political actors came to explain Indigenous suffering in the universalized register of humanitarianism. I analyze how Indigenous leaders participated in elaborating Aboriginal healing

\footnotetext{
${ }^{17}$ For an argument that contemporary analyses of the relationship between (settler) colonialism and humanitarianism need to attend more closely to historical contexts, see van Krieken 2016.
} 
as settler-humanitarian discourse via the Royal Commission on Aboriginal Peoples (1991-1996), which was in part a settler-state response to Kanehsatake, and the advocacy work of the Assembly of First Nations under Fontaine's leadership. ${ }^{18}$ Alongside the legal system and the largest class-action lawsuit in Canadian history, these Indigenous-led institutions played central roles in translating former students' accounts of residential school experiences into representations of traumatized victimhood that inspired settler-humanitarian sympathy and interventions.

I interpret Indigenous leaders' representations of social suffering in settlerhumanitarian terms as a politically savvy move that enables their communities to access resources, particularly while neoliberal fiscal retrenchment has constrained public expenditures on healthcare and social services. But my analysis also suggests that humanitarian interventions entrench, rather than challenge, settler-colonial domination of Indigenous lives. In a final section I discuss some of the social and political effects, likely unintended by their Indigenous proponents, of the Settlement Agreement and historical trauma discourse.

PERIODIZING INDIGENOUS CHILD-RESCUE: IMPERIAL AND

NEOLIBERAL SETTLER-HUMANITARIANISM

In the late nineteenth century, leaders of the nascent settler-states of Canada and Australia claimed the mantle of modern, moral governance, legislating for the Christian "care" and paternalistic "protection" of Indigenous peoples. They distanced themselves from the murderous violence of the colonial frontier, condemned by humanitarians as an evil to rival the recently abolished slave trade (Lester and Dussart 2014). ${ }^{19}$ At the same time, the spirit of capitalism compelled the growth of settler-economies based on agriculture and extraction, and economic growth demanded ongoing Indigenous dispossession. Humanitarian interventions to remove, contain, and forcibly remold Indigenous children afforded an organized means of dispossession, one that enabled territorial access but was also consistent with the rule of law and state actors' claims of moral governance. $^{20}$

18 The RCAP was overseen by seven commissioners, of whom four were Indigenous: Paul Chartrand, Co-Chair Georges Erasmus, Viola Robinson, and Mary Sillett. Prime Minister Brian Mulroney's Conservative government established the RCAP in 1991 in response to several political developments: the salient impasse between Indigenous sovereignty struggles and the settler-state, represented by the Kanehsatake resistance, failure of the Meech Lake constitutional accord, and mounting global criticism of Canada's Indigenous human rights violations.

19 Humanitarians' increasing influence on British imperial governance was first demonstrated by legislation to ameliorate conditions of enslaved peoples in the Caribbean in the 1820s. It was consolidated by the work of the Parliamentary Select Committee on Aborigines (British Settlements) (1835-1837), whose members framed Indigenous peoples' suffering as a problem of insufficient governance in the settler-colonies (Lester and Dussart 2014).

20 As Stoler (2010 [2002]) says, this model was widely adapted in colonial settings. 
Crucially, settler-humanitarians de-coupled the welfare of Indigenous children from the well-being of their parents and harnessed children's "care" to the future of the settler-state. This disavowal of Indigenous kinship ties was enabled by late nineteenth-century evangelists' influential, radical reconceptualization of children as citizens-in-the-making (Hillel and Swain 2010; Stoler 2010 [2002]). Prior to evangelists' advocacy efforts, British society understood children to be the property of their parents and therefore of little public interest. Eighteenth-century missionaries in Canada, for instance, were unable to marshal the support of colonial administrators to compel Indigenous children to attend their schools (Miller 1996).

Central to British and settler-colonial elites' reconceptualization of children as future citizens was the emergent moral and scientific understanding of children as distinctly malleable and vulnerable (Hillel and Swain 2010). Citing German scientific discourse, imperial child-rescue evangelists wielded this idea of peculiar malleability to argue that even the most debased child is amenable to rehabilitation into a moral, hard-working citizen (ibid.). ${ }^{21}$ In contrast, adults (more pointedly, impoverished and/or Indigenous parents) were portrayed as lacking this plasticity and therefore less amenable to "uplift" (ibid.). Alongside their distinct malleability, children's newly identified, special vulnerability imposed new moral and material obligations on Christian adults, particularly to remove "neglected" children from the deleterious influences of intransigent kin (ibid.).

This unprecedented opposition of children's interests to those of their parents had devastating implications for poor and marginalized families across Britain and the empire (Hillel and Swain 2010). But the scale and duration of the social devastation that ensued were greatest for Indigenous families in the settler-colonies (Haebich 1992; Jacobs 2009). ${ }^{22}$ The automatic categorization of virtually all Indigenous families as neglectful and immoral was overdetermined, first by the material deprivation imposed by settler-colonialism and second by Christian reformers' devaluation of Indigenous wild-harvesting livelihoods and interconnected kinship relations (van Krieken 2010). Settlerhumanitarians equated Christianity with cleanliness and domestic industry, and indigeneity with filth and backwardness, and represented Indigenous women in particular as inadequate mothers (Jacobs 2009; Kelm 1998). In Australia, reformers bolstered advocacy for the removal of Indigenous children with allegations of immoral kinship practices that spanned incorrect infant handling, infant betrothal, and the enslavement of women (Jacobs 2009).

21 The rise of eugenicist ideas about heredity in late nineteenth- and early twentieth-century Europe spurred an intensification of reformers' long-standing arguments about the countervailing power of environment to mold character (Hillel and Swain 2010; see also Stoler 2010 [2002]).

${ }^{22}$ These authors describe how legal obstacles that prevented state agents from unilaterally removing white children were established much earlier. 
As recently as the late 1950 s, Australian administrators publicly described Indigenous family life as "inherently flawed, fragile and basically worthless, producing only illness, disease, drunkenness, filth and degeneracy" (van Krieken 2004: 141). We will see that contemporary public discourse on Indigenous families under settler-state neoliberalism displays continuities with this discourse.

In Canada, colonial administrators came to favor assimilation as a costeffective approach to colonization in the context of the waning military significance of Indigenous peoples after the War of 1812 and an increasing influx of British settlers from the 1820s (Miller 1996). Legislative efforts to assimilate Indigenous adults failed resoundingly. Over the six years following the 1857 Act to Encourage the Gradual Civilization of the Indian Tribes, the strategy of enfranchisement, which entailed inciting adult men to renounce their Indian status for full citizenship rights, attracted only one man (Milloy 1999: 18-20). While missionaries continued to proselytize, Canadian administrators abandoned a policy-led approach to adult assimilation for nearly a century, until the advent of social welfare (Shewell 2004).

Imperial humanitarians' intensified interest in Indigenous welfare onward from the 1830 s inspired the emergence of a new policy focus on assimilating children. This crystallized in the residential schools, a joint venture between Christian churches and the nascent settler-state's Department of Indian Affairs. Since the late eighteenth century, British missionary societies had experimented with residential education in several locations in the Canadian colonies, and by the 1840 s the colonial administration's new interest in assimilation had converged with these projects (Miller 1996). Following Confederation in 1867, Indian residential schools became federal policy in 1880 and endured for over a century. Attendance was enforced with intensifying coercion following 1894 and 1920 amendments to the Indian Act (Miller 1996; Milloy 1999). By 1923, 5,347 Indian-status children were attending seventy-one schools, and by 1953 they exceeded ten thousand (Milloy 1999: 52, 214). ${ }^{23}$

In Australia, settler-humanitarians initiated Indigenous child-removal policies in a different context, one in which church and government collaborations were initially inspired by prolonged frontier killing rather than assimilationist desires. $^{24}$ From the first settlement in 1788, Anglo-Celtic settlers gained control of Indigenous territory by killing men, women, and children and exploiting survivors for agricultural, domestic, and sexual labor (Rogers and Bain 2016). Conveniently disregarding that such settler violence enabled

\footnotetext{
23 Although government policy intended the schools to be for children with Indian status, as defined by the Indian Act, a significant number of Métis children also attended (Chartrand, Logan, and Daniels 2006; Logan 2008).

24 In their recent review of historiographic evidence, Rogers and Bain (2016) define the frontier period, characterized by settler massacres of many tens of thousands of Aboriginals, as spanning 1788 (the first settlement at Sydney) to 1928 (the Central Australian Coniston massacre).
} 
appropriation of Indigenous territory and, therefore, the colonial economy, metropolitan and colonial governments styled themselves as modern, Christian protectors of Aborigines against wanton settler violence, and by the $1830 \mathrm{~s}$ this humanitarian discourse was central to Australian missionary and colonial policy (Lester and Dussart 2014; Rogers and Bain 2016). ${ }^{25}$ Missionaries and colonial administrators relocated Aboriginals from their traditional territories to missions and reserves in the name of "protection," simultaneously pursuing conversion to Christianity and agriculture and freeing up Indigenous land for pastoralist settlers (Haebich 1992; Lester and Dussart 2014). With anthropologists, imperial humanitarians constructed a narrative that they were alleviating the suffering of a vulnerable race that was expected to die out completely. As Rogers and Bain note, "This extinction narrative covered over the policy choices that were made in the pursuit of profit" (2016: 88).

But by the last decades of the nineteenth century, the extinction narrative was belied by a growing population: the descendants of Indigenous women and European or Asian men. The goal of Australian humanitarians then shifted from a narrow focus on protecting survivors of a dying race to enabling "absorption" of these children into settler society (Short 2008). In the decades before and after Australian federation in 1901, a series of Aboriginal protection and child-removal policies was enshrined in each of the colonies (and later, the states) (Haebich 1992; van Krieken 2004). ${ }^{26}$ These policies culminated in the legal enshrinement of the settler-state as guardian of nearly all Indigenous children, including those with living parents, and authorization of Aboriginal Welfare authorities to use force or coercion to remove those deemed "neglected" (ibid.). Indigenous child-removal practices continued through the 1950s and 1960s and debate continues over the total number of children who were removed, with estimates ranging from seventeen thousand to fifty thousand (Short 2008). ${ }^{27}$

In both Australia and Canada, removing Indigenous children and remolding them as agricultural and domestic laborers served the settler-state's political and economic interests in claiming Indigenous territory. Humanitarians understood that such labor held "redemptive value" for debased children (Hillel and Swain 2010: 116) and redressed the ignorance and idleness they imagined were inherent to Indigenous lifeways. Children were trained in menial skills to form

\footnotetext{
${ }^{25}$ The Australian colonies lacked military or trade alliances to structure European-Indigenous relations; missionaries began work contemporaneously with settlement and early colonial governance, and shortly before the rapid ascent of imperial humanitarianism (Nettelbeck et al. 2016). In Canada, by contrast, missionary activity (including the prototypes for residential schools) predated large-scale European settlement and settler-colonial governance by many decades.

26 The exception was Tasmania, where administrators reported Aboriginals had been eliminated through mass killing and humanitarian relocation (Jacobs 2009). The policies were strengthened around 1915, and again in the 1930s (ibid.).

${ }^{27}$ Record-keeping was deliberately minimal, since Australian child-removal practices were intended to permanently severe ties between children and families (Robert van Krieken 2004).
} 
a low-cost workforce of industrious Christian, colonial subjects. In Australia, children were to be absorbed into white settler society through placements as domestic or agricultural workers with settler families (Haebich 1992; Short 2008; van Krieken 2010). In Canada's residential schools, under the "half-day system" in place until 1951, older students spent only half of their school-day in the classroom and the other half laboring in school kitchens and farms (Truth and Reconciliation Commission of Canada 2012).

The imperial humanitarian "rescue" of Indigenous child-victims exemplifies the paradox at the heart of settler-colonial governmentality: the elimination of Indigenous people and interventions to address Indigenous welfare are not merely co-existent, but interdependent. Making sense of this paradox requires understanding the liberal (settler) subject as defined by the dialectic of rational self-interest and morality. As Andrea Muehlebach (2012) explains, liberals invoke morality in order to displace the aggression inherent to capitalism. Drawing on Marx, she argues that in this dynamic dialectic of morality and material self-advancement, liberal morality is proportionate to capitalist exploitation. This means that in an era of intensified exploitation, "morals and ethics [become] public cultural necessities that help provide collective meaning-and help orient collective practice meaningfully - at a moment when the social fabric is strained" (ibid.: 22). Humanitarian reason enabled these settler societies to craft enduring mythologies of national benevolence, discursively reworking violent Indigenous dispossession as Canada's "Gentle Occupation" and Australia's “Quiet Continent” (Nettelbeck et al. 2016: 206).

These national myths were challenged by revelations of the exploitation and abuse of Indigenous children in state institutions. In February 2008, newly elected Australian Prime Minister Kevin Rudd offered an official apology to the "Stolen Generation," the former Indigenous child-victims of imperial settler-humanitarianism. ${ }^{28}$ Some months later, Canadian Prime Minister Stephen Harper followed suit, offering his apology to the former residential school students. In both settler-nations since the $1990 \mathrm{~s}$, the figure of the historic Indigenous child-victim has become the fulcrum for national redemption projects of "healing" and "reconciliation." But even while settler-state atonement for imperial child-rescue projects is ongoing, neoliberal incarnations of settlerhumanitarian child-rescue have emerged. Next, I examine how the contemporary Indigenous child-victim's currency is overdetermined by relations between Indigenous peoples and the settler-state under neoliberalism.

\footnotetext{
28 Authors of the 1997 report Bringing Them Home originally recommended that Australian governments and others involved in removing Indigenous children should apologize to Indigenous peoples. The now-ubiquitous phrase "The Stolen Generation," coined by historian Peter Read, was popularized through the same report.
} 


\section{Settler-Humanitarianism as (Neo)Liberal Statecraft: Rescuing Indigenous Child-Victim Citizens}

In 1993, in an unheated shack in Utshimassits, Labrador during -40C degree winter conditions, a local policeman filmed Innu children sniffing solvents and proclaiming their intent to commit suicide. The footage provoked international media headlines such as "Canada's Third World," and inspired human rights advocates to mobilize Innu children as symbols of the settler-state's neglect of Indigenous communities. ${ }^{29}$ But state agents effectively navigated the ensuing media storm, positioning themselves as the rightful, responsible protectors of these Indigenous child-victims. In contrast, Innu parents and political leaders were vilified by state-employed health professionals and other political actors as immoral and backward for failing to protect their children (Samson 2009). Social workers removed nine Innu children to the "care" of a state group-home, while fourteen others, with their parents, were flown across the country for "Aboriginal healing" at Nechi Institute. ${ }^{30}$ Innu Elders expressed concerns about this state-imposed, "pan-Native" approach to "healing" their children, which decentered Innu social relations and violated their collective rights to autonomous social reproduction (Samson 2009). ${ }^{31}$ Their concerns were disregarded.

Fourteen years later, in seventy-three Aboriginal communities in the Northern Territory, Australian state actors invoked the suffering Indigenous child-victim to legitimate an intervention that was simultaneously humanitarian and military (cf. Fassin and Pandolfi 2010). ${ }^{32}$ More than merely reminiscent of imperial child-rescue projects, Prime Minister John Howard "explicitly framed the intervention as a renewal of colonialism's civilising mission ... cast[ing] remote communities as heretofore insufficiently colonised zones, to which the sovereign's rule of law must now finally be extended" (Stringer 2007: n.p.). Indigenous communities quickly recognized what was at stake and decried the settler-state's invocation of "child sexual abuse as the Trojan horse to resume total control of our lands" (ibid.: n.p.). The invasion and accompanying legislation entailed multiple violations of collective Indigenous rights: imposition of far-reaching legal changes to systems of land tenure, labor, and governance; mandatory medical inspections of children; restrictions on welfare; and privatization of housing (Howard-Wagner 2010; Stringer 2007; Watson 2010). Settler-state actors framed these interventions as a "national

\footnotetext{
${ }_{30}^{29}$ See, for example, Survival International's (1999) report.

30 Established by Indigenous activists in western Canada in 1974, and funded by the federal National Native Alcohol and Drug Addictions Programme (NNADAP), the Nechi Institute exemplifies the institutionalization of Native healing praxis.

31 Leeanne Simpson (2008) provides a critique of "pan-Aboriginal" approaches.

32 The first public report of alleged child abuse in the Northern Territory was Wild and Anderson 2007.
} 
emergency," as urgent, morally irreproachable, and linked to Australian interests (Howard-Wagner 2010).

I assert that these (neo)liberal settler-humanitarian rescue missions constitute settler-states' political response to the growing international recognition of collective Indigenous legal and political rights (see also Million 2013). The global Indigenous rights movement has gained ground since the 1980s, culminating in the 2007 United Nations Declaration on the Rights of Indigenous Peoples. ${ }^{33}$ Concurrently, both Australia and Canada embarked upon a neoliberal quest for limitless economic growth centered on natural resource extraction. Collective Indigenous rights threaten this quest by potentially affording not only legal bases for limiting settler-states' appropriation of Indigenous territory and natural resources, but also a moral discourse for challenging these states' self-representations as benevolent.

Settler-humanitarianism responds to these exigencies by invoking the moral imperative of Indigenous child-rescue to legitimate ongoing state domination of Indigenous peoples (see also Stringer 2007). In the Northern Territory, this claim to moral righteousness was instrumental to the Australian government's privatization of collectively owned Indigenous land, which enabled corporate mining, tourism, and nuclear-waste dumping (Stringer 2007). ${ }^{34}$ The reassertion of settlerstate authority over the Innu, via the 1993 "rescue" of their children, followed two decades of Innu protests against Canada's permanent military presence and illegitimate natural resource extraction on their territory. ${ }^{35}$

The target of these neoliberal rescue-missions was the Indigenous "childvictim citizen" (Chen 2003). This contemporary victim of abuse and trauma is distinct from the debased native child of the imperial period, who only became a citizen-in-the-making once rescued and undergoing rehabilitation as a Christian manual laborer. Not only do settler-states and their publics recognize contemporary Indigenous child-victims as citizens, but their citizenship rights, predicated on both innocence and victim status, are precisely defined by their capacity to provoke settler sympathy. Public compassion legitimates their need for state protection and care, even under fiscal neoliberalism (Chen 2003; Ticktin 2011).

Indigenous parents, however, have seen their citizenship rights eroded, as have other poor, marginalized, and particularly racialized adults, as a result of

33 This Declaration was adopted by a large majority of the UN General Assembly in 2007, after over twenty-five years of development, but was opposed by Australia, Canada, New Zealand, and the United States. Australia reversed its opposition in 2009, New Zealand and the United States in 2010, and Canada in 2016. There remains significant variation in how it is interpreted, however.

34 This was done by amending the 1976 Aboriginal Land Rights (NT) Act.

35 The Canadian military base is at Goose Bay. Among various hydroelectric, mining, timber clearcutting, and commercial fishing projects, most egregious was the Upper Churchill Falls hydroelectric station. Completed in 1974, it flooded thousands of kilometers of Innu territory, destroying caribou habitats and burial grounds. Innu Nation website, 11 May 2016: http://www.innu.ca/index. php?option=com_content\&view=article\&id=10\&lang=en (last accessed 30 Apr. 2017). 
neoliberal social policy and linked discourse. ${ }^{36}$ Globally, humanitarians advocating for child-victim citizens, ranging from suicidal Innu to HIV-positive babies in South Africa, contrast these children's innocence with the culpability of their parents (Chen 2003; Fassin 2012). The corollary of the child-victim citizen's moral and political traction under neoliberalism is the intensified vilification of poor parents. In North America, public discourses grounded in fiscal austerity, such as "compassionate conservatism," have delegitimized public resource allocation for the collective needs of families (Berlant 2004; Briggs 2012). The rhetoric of the U.S. "War on Drugs," with its stock figure of African-American and Latino "crack babies," fuels the populist condemnation of poor mothers (Briggs 2012). The public health policing of pregnant women and sensationalized representations of Indigenous children damaged by fetal alcohol syndrome have intensified the apprehension of Indigenous children by Canadian and American child welfare authorities (Briggs 2012; Oldani 2009; Tait 2009). Indigenous health and social service workers are increasingly constrained by structures that oppose the interests of Indigenous child-victim citizens with those of their vilified parents. ${ }^{37}$ Internationally, Indigenous feminists are at the forefront of developing alternative paradigms which, for example, conceptualize interpersonal violence as a collective issue, and challenge the systematic criminalization of Indigenous men (Deer 2009; Million 2013; Susskind 2008; Women's Earth Alliance 2016).

The ascent of the child-victim citizen not only erodes Indigenous adults' already-tenuous rights as citizens of settler-nations, but as citizens of Indigenous nations this development threatens their already-disputed claims to sovereignty and self-governance. The paradox of (neo)liberal settler-humanitarianism is that substance abuse and interpersonal violence, which often intensify as material conditions deteriorate under neoliberal public policy, provide moral cover for child-rescue interventions such as those in Innu territory and Australia's Northern Territory. These interventions reinforce settler-publics' perceptions of Indigenous peoples as incapable of self-government and legitimate ongoing, paternalistic state interventions as urgent and essential. Meanwhile, Native healing praxis, which addressed precisely these forms of collective social suffering, has been partially displaced by Aboriginal healing policy centered on historic child-victims. As the latest formulation of settlerhumanitarianism, Aboriginal healing continues the individualistic human rights focus of the neoliberal child-rescue mission. The difference is that the Indigenous child-victim to be rescued is the "inner child" of residential school survivors (Ivy 1993).

\footnotetext{
36 By citizenship rights I mean entitlements to adequate income, housing, health care, education, clean water, and nutrition, all undermined by neoliberal public policy.

37 Joseph P. Gone, personal communication with the author, 26 May 2015.
} 
SETTLER-HUMANITARIAN HEALING FOR THE TRAUMATIZED,

INDIGENOUS CHILD-VICTIM

Chief Phil Fontaine's 1990 call for "healing" hinged on a particular framing of suffering, newly-emergent at the time of his interview, defined by trauma, induced by childhood sexual abuse, and etiological of present-day dysfunction. "Aboriginal healing" reflects how the traumatized "other" "defines the universal" for our age (see also Barnett 2011: 11). The corollary is that Native healing praxis, whose proponents understood Indigenous suffering and healing as collective social experiences linked to kinship, language, and territory, was pushed to the margins of public discourse. This displacement is vividly illustrated by the mandate of the Aboriginal Healing Foundation to concentrate on "healing from physical and sexual abuse." ${ }^{39}$ In 2008, Dr. Mike DeGagné, the Foundation's executive director, explained to me how this unequivocal mandate constrained the scope of fundable interventions: "We were limited to a very specific type of trauma, and a very specific type of program to deal with that trauma." obliged to reject the majority of Indigenous communities' proposals for healing projects since they lacked this prescribed focus. As DeGagné elaborated, "Even some basic things, like language programs and the very important role of language and culture, had to be left out, because that wasn't an acceptable part of our mandate.... This was a way to limit [government expenditure]."

The ethos of healing the child-victim of the residential schools was first elaborated through the work of the Royal Commission on Aboriginal Peoples (RCAP) in the 1990s, which prompted the federal government's first foray into Aboriginal healing in 1998, the "Gathering Strength" policy. Discussions under the RCAP, particularly those led by healthcare experts, crystallized the Indigenous child-victim citizen as a uniquely deserving recipient of public sympathy (and resources) in the context of delegitimized public service expenditure. Then, from 2001, negotiations between the federal government and the Assembly of First Nations (AFN) and its legal advisors, under Fontaine's leadership, further elaborated the meaning of Aboriginal healing, culminating in the 2006 Indian Residential Schools Settlement Agreement. As I shall demonstrate, the AFN and its legal allies wielded a compelling cost-benefit analysis to frame financial-compensation-as-healing as a cost-effective outlay for the redemption of the Canadian settler-state's humanitarian reputation.

Although Aboriginal healing policy came to highlight the irrefutable linkage between residential school attendance, sexual abuse, and trauma,

\footnotetext{
38 Trauma was formally recognized by the American Psychiatric Association as a diagnosable disorder in 1980 .

39 The mandate was established as part of the Canadian government's initial (1998) policy response to allegations of abuse in the residential schools.

${ }^{40}$ Mike DeGagné, oral history shared with the author in 2008.
} 
earlier representations of experiences in the schools were more nuanced. Autobiographical and historical accounts published prior to Fontaine's 1990 media announcement included, but also ranged beyond, individual abuse, and offered up a range of subject positions for Indigenous children (Haig-Brown 1988; Johnston 1988). In these accounts, chronically hungry, malnourished students stole and shared food in camaraderie, maintained dignity in the face of punishment, enjoyed humor at the expense of school authorities, devised tactics for boys and girls to interact across institutionally imposed barriers, and ran away from the schools. In research commissioned by the Assembly of First Nations (1994), former students describe solidarity among children as a prominent theme. Older children inspired younger ones with acts of defiance, and also cared for them, for example by sharing food they plundered during the night. In one compelling account, an older boy deliberately urinated in his bed so that he could share in his younger cousin's punishment of being publicly stripped and paraded in front of the other boys. This compassionate gesture had a lasting impact on the younger child: he went on to support another child being punished for poor reading by feigning inability himself, and then used the opportunity of their shared punishment to assist the boy who was struggling.

Experiences of violence and victimization are clearly discernible in these accounts, but the children are not narrowly portrayed as victims - they are rebels, co-conspirators, leaders, allies, and even heroes. They act in ways that can be read as anticolonial resistance, and they can serve as inspirational role models for those struggling against contemporary settler-colonial domination. These representations privilege collective responses of mutual care and organized resistance in the face of violence and suffering, and challenge portrayals of Indigenous children as mere victims. But such complex analyses were displaced by narrow representations of the decontextualized, sexuallyabused, and traumatized Aboriginal child-victim. The latter figure became ubiquitous through the late 1990s as public discourse on healing from residential schools gained momentum through court cases, public hearings, interim RCAP publications, and media coverage.

The threat of litigation was an important driver of both the Canadian state's engagement with "Aboriginal healing" and the singular focus on sexual abuse. As the Aboriginal Healing Foundation's Mike DeGagné explained, "The government was only prepared to address needs that were the ones that people were lined up out the door to take to court.... Loss of language and culture is not a compensable issue in court, but physical and sexual abuse is. And it was very strictly limited in that way." ${ }^{41}$ Litigation for residential school experiences differed from many other legal cases initiated by Indigenous people in Canada: its emphasis on injury and loss, and consequent

${ }^{41}$ Ibid. 
reliance on tort law, narrowed the conditions of recognition for injury (Blackburn 2012). Indeed, the failure of most early residential school cases contrasted strikingly with the successful efforts of Indigenous polities to advance sovereignty claims through the courts between the 1970s and $1990 \mathrm{~s} .{ }^{42}$

In contrast to the earlier sovereignty claims, which challenged Eurocentric definitions of land ownership, the legal currency of childhood sexual abuse is predicated on the widely-held assumption that this form of suffering derives from universalized psychological effects, devoid of historical and political particularity. As anthropologist Carole Blackburn notes in her analysis of court proceedings in one of the early lawsuits, brought by former students in British Columbia, complex, collective losses - of family ties, language, and place-based Indigenous knowledge-were rendered legally significant only to the extent that they "aggravated the negative psychological effects of the abuse ... suffered" (ibid.: 293). As of 2001, the only successful legal cases brought by former students were those in which the litigants had previously established in a criminal trial that sexual abuse had occurred (Lewellyn 2002). Blackburn (2012) concludes that as an institution through which to pursue justice for Indigenous experiences of multi-faceted violence and loss, not only is the dominant judicial system constraining, but it risks exacerbating suffering through artificial individualization and the reification of sexual assault. As we shall see, the Settlement Agreement also perpetuated Indigenous suffering in this way.

\section{The RCAP and Aboriginal Healing as Public Policy}

The Royal Commission on Aboriginal Peoples constituted a second crucial forum for crystallizing the traumatized child-victim of sexual abuse as the central subject of Aboriginal healing discourse. The RCAP was established by Mulroney's Conservative government in 1991 (see note 18, this paper). In 1996, the Commission's long-anticipated, five-volume report documented myriad injustices and enduring social suffering inflicted by colonial policies and advocated a profound restructuring of political and social relations between Indigenous peoples, settler society, and the state. ${ }^{43}$ But the public discourse that followed quickly narrowed to focus on former students' experiences of abuse in the residential schools, and many other significant recommendations were largely neglected (Aboriginal Rights Coalition 2001).

In 1993, the RCAP commissioners hosted Indigenous health professionals, community leaders, and their allies at a National Roundtable on

42 These included significant Supreme Court of Canada rulings. In Calder v. Attorney-General of British Columbia (1973) Canadian law first recognized Aboriginal title, and R. v. Guerin (1984) established the Canadian government's fiduciary duty to First Nations, stemming from the sui generis right of Aboriginal title.

${ }^{43}$ For a critical discussion of the RCAP, see Turner (2006). 
Health and Social Issues, a three-day event in Vancouver. ${ }^{44}$ Participants prioritized "victims of residential schools" as one of five groups whose needs ("wounds") "require targeted attention and specific policy frameworks" (RCAP 1993: 23). Roundtable discussion did not highlight the significant bodily sufferings and premature deaths suffered by thousands of children, including from malnutrition and tuberculosis, injury by neglect and physical violence, and the exposure suffered by those who ran away and never made it home (Kelm 1998; Miller 1996; Milloy 1999; Mosby 2013). Instead, the "wounds inflicted by residential schools" that needed healing were wounds of trauma: the ongoing psychic consequences of experiences endured many years before. As the rapporteur summarized, "Although the impact of residential schools on Aboriginal society must be considered in broader terms than health consequences, many [Roundtable participants] linked their own and others' experiences in the residential schools to problems of alcohol abuse, suicide, and family violence in Aboriginal communities today" (RCAP 1993: 23). Participants were primarily concerned with residential school experiences as etiological of contemporary dysfunction, echoing Phil Fontaine's CBC interview three years earlier.

In the years since Fontaine's interview, trauma has become central to global humanitarian discourse because it evokes "an irrefutable reality linked to a feeling of empathy" (Fassin and Rechtman 2009: 4). Not only is the authenticity of the traumatized victim's suffering accepted without question, but because trauma is imagined to be a universal response to experiences of violence, magically unmediated by the particularities of social and historical context, the traumatized victim has become "the very embodiment of our common humanity" (ibid.: 23). In the report of the RCAP Roundtable, we can trace how healing from trauma partially eclipsed earlier, collectivist understandings of Native healing praxis.

First, given that the RCAP's recommendations on residential schools and healing ultimately had a huge impact, it is noteworthy that neither the commissioners nor participating academics seemed to anticipate that residential school experiences would be a priority issue for the Roundtable — not one of the eleven papers commissioned for the Roundtable and published in its report addressed the topic. Moreover, the report's background sections invoked the older understandings of healing associated with grassroots movements, as a long-term, collective, holistic, and multi-faceted process linked to political change, including the equitable delivery of public services. For example, Mohawk physician Louis T. Montour, in his Introduction to the report, summed up discussions

\footnotetext{
44 In addition to the RCAP commissioners, most of the eighty-plus participants in the Roundtable were Indigenous health professionals (physicians, nurses, community health representatives, social workers, and administrators). Others participants included four Elders, Indigenous and nonIndigenous academics, and non-Indigenous health professionals.
} 
of healing in prior RCAP hearings as concentrating on "self-esteem," "recognition of traditional healing and traditional culture," "holistic approaches to critical symptoms," "Aboriginal and community control of programming," and "parity in medical and social service standards" (RCAP 1993: 11). Anthropologist and Roundtable rapporteur John O'Neil observed in his report that many participants asserted that healing "is a way of life rather than a segregated or specialized activity" (ibid.: 17), and that retention and recovery of languages is central to Indigenous well-being.

Against this backdrop, it is jarring to encounter calls for policy directing "targeted attention" to particular categories of victims, presented as a group consensus in O'Neil's report as rapporteur. It is notable that most of these categories-"victims of residential schools," "victims of sexual abuse and domestic violence," and "children with fetal alcohol syndrome"-signify "innocent" victims. Their suffering is attributed to interpersonal and sexual violence, or parental substance abuse, representations that invoke affective public responses associated with "compassionate conservatism" (Berlant 2004). Linking residential school experiences to a special form of victimhood warranting public compassion and resources is, I suggest, symptomatic of the re-emergence of humanitarian reason as part of neoliberal morality (see also Muehlebach 2012).

Scholars have linked the recent, global ascent of humanitarian reason to the end of the Cold War and the rise of fiscal neoliberalism, pointing to pervasive disenchantment with anticolonial struggle and other collective political movements, shrinking welfare states, and the rise of corporate sponsorship of humanitarian interventions (Barnett 2011; Fassin 2012; Ticktin 2011). As Andrea Muehlebach argues, with the expansion of the domain of the market, neoliberal morality is not necessarily in thrall to market neoliberalism; rather they coexist "in productive tension" (2012: 24). Particularly since the 1990s, social movements historically associated with demands for radical economic and political transformation have embraced humanitarian discourse as an expression of morality calculated to attract funding (Barnett 2011; Fassin 2012; Ticktin 2011). The displacement of anti-poverty movements by "child poverty" campaigns, in Canada and globally, vividly illustrates this shift (Chen 2003). Such emergent representations of victimhood enable individual claims on public compassion and resources even as collective entitlements are eroded.

The traumatized Aboriginal child-victim's traction in the RCAP Roundtable forum, I suggest, reflects Indigenous leaders' astute understanding that affectively-compelling victimhood enables access to public resources during a period of fiscal austerity (Berlant 2004). At that time, Mulroney's Conservative government had recently invoked the recession to justify cutting tens of millions of dollars from the budgets of Indigenous advocacy and service organizations (Cohen, Morrison, and Smith 1995). Given this context, it is 
significant that one of two keynote speakers invited by commissioners to address the Roundtable was Robert Evans, a health economist whose analyses align neatly with a neoliberal fiscal agenda, rather than with understandings of Indigenous healing as a collective social process. Evans's published work on "population health" steers Canadian health policy discourse toward a diversionary focus on "wealth creation," neglecting the social production of health inequities and justifying further dismantling of the welfare state (Poland et al. 1998). His inclusion in the program supports my interpretation that some Indigenous leaders and their allies were, at this historic juncture, tactically moving away from collective, social understandings of suffering and healing in pursuit of a new approach geared to attracting public funds despite fiscal retrenchment. ${ }^{45}$

This analysis is also supported by a narrative shared by John O'Neil, the rapporteur, which conveyed disenchantment with nuanced analyses of colonialism and Indigenous health. In a section entitled Aboriginal Health Policy for the Next Century, O'Neil's account spotlights Eric Shirt, co-founder of two influential healing institutions in Canada, the Nechi Institute and Poundmaker's Lodge. ${ }^{46}$ (Recall that the former provided the "pan-Aboriginal" healing services for "rescued" Innu children, described previously.) O'Neil recounts an argument he had with an unnamed anthropologist during an earlier workshop in Australia, in which Shirt argued forcefully for individualistic treatment programs for Indigenous alcohol abuse, against the anthropologist's socialhistorical perspective. Shirt's pragmatic argument was that governments are reluctant to fund programs based on a broad etiological model highlighting colonization's social effects because such programs have no clear endpoint. O'Neil concluded that "“colonialism' as a central explanation for current Aboriginal health conditions may have limited applicability" (RCAP 1993: 28). In other words, to attract public funding, healing programs had to understand Indigenous suffering in ways that aligned with dominant political ideology. ${ }^{47}$

Roundtable participants' tactical focus on the figure of the traumatized former residential school student was validated five years later when, in January 1998, the settler-state paternalistically embraced this Indigenous childvictim as a citizen, uniquely deserving of public sympathy and resources.

\footnotetext{
45 Since Evans was one of only two keynote speakers invited, my interpretation is based on the assumption that his invitation was supported by a majority of the commissioners.

46 Both were funded from the 1970 s via the federal government's National Native Alcohol and Drug Addictions Programme.

47 I do not claim that all commissioners and participants subscribed to this view. Illustrating divergence among commissioners on a closely related topic, Métis law professor Paul Chartrand chose not to endorse a subsequent RCAP report on suicide that presented a relentlessly bleak depiction of Indigenous lives under colonization. Chartrand published a statement criticizing the report for neglecting important differences among Indigenous communities and its universalizing approach to policy recommendations (Royal Commission on Aboriginal Peoples 1995).
} 
Minister for Indian Affairs and Northern Development Jane Stewart delivered the Statement of Reconciliation that signaled the re-emergence of settlerhumanitarianism in Canadian policy discourse. Delivered against the backdrop of growing legal pressure from residential school court cases, this statement was part of Gathering Strength, the federal government's belated policy response to the RCAP's final report. Gathering Strength also established the Aboriginal Healing Foundation, with its narrow mandate to facilitate healing from sexual and physical abuse.

Stewart's Statement of Reconciliation has been interpreted as the government's defensive response to mounting court cases and the RCAP report. But it is also pertinent to consider the role of public apology and sympathy in settler-state-building (Ahmed 2004; Rutherford 2009). Similarly to the politics of recognition (Coulthard 2014), settler-state agents' expressions of sympathy for Indigenous people are predicated on a degree of universalization, a presumption of likeness and alignment of perceptions and experiences that allows settlers to believe they have actually witnessed the cause and experienced the sensation of the Indigenous other's feelings (Rutherford 2009). At the same time, this sympathy flows along the unchallenged racialized hierarchy underlying both colonization and humanitarianism (ibid.), and effectively reasserts the authority of the settler-state to define Indigenous suffering as legitimate.

Minister Stewart's statement discursively established sexual and physical abuse as the benchmarks by which the settler-state would recognize the legitimate child-victims of residential schools. While she acknowledged, briefly, that the school system separated children from families and communities and prevented the transmission of Indigenous languages and knowledge, it was only "the victims ... those individuals who experienced the tragedy of sexual and physical abuse," to whom she apologized on behalf of the Government of Canada: "To those of you who suffered this tragedy at residential schools, we are deeply sorry" (my emphasis). This first official apology elided the multiple forms and experiences of violence inflicted on individuals, families, communities, and nations by the residential school system as well as the myriad ways in which they challenged and resisted the schools. And like Harper's subsequent apology, Stewart's did not acknowledge state and church culpability.

Ultimately, this apology and the establishment of the Aboriginal Healing Foundation were insufficient to staunch the flow of court actions brought by former students against the government and the churches. From 2001, negotiations toward an out-of-court settlement provided a new site where political actors, variously affiliated with the settler-state, Indigenous governments, and the legal professions, further reformulated Indigenous healing in settlerhumanitarian terms. 


\section{The Assembly of First Nations and Financial Compensation as Aboriginal Healing}

The Assembly of First Nations substantially influenced the Settlement Agreement's content through a compelling synthesis of humanitarian and financial rationalities that drew extensively on legal expertise. Indian Residential Schools Resolution Canada (IRSRC), a new federal department established in 2001 under the deputy prime minister with the mandate to negotiate an out-of-court settlement, released the government's initial Dispute Resolution Plan in 2003. The Assembly of First Nations leadership, dissatisfied with both the process followed and the amounts of compensation proposed under this plan, hosted a conference aimed at developing a critical response. This materialized in the 2004 Report on Canada's Dispute Resolution Plan to Compensate for Abuses in Indian Residential Schools.

Although the Assembly of First Nations report was successful in shaping the content of the eventual settlement, it reproduced the flawed logic of corrective justice inherent to tort law (Lewellyn 2002), which residential school survivors had found so unsatisfactory in earlier litigation. The report's authors posited that material reparations, paid by a perpetrator to their victim, can remedy inflicted harms which are manifestly not material in form. In pursuing the largest possible financial settlement for the former students, the AFN leadership aligned themselves with the settler-humanitarian premise of the state's Aboriginal healing project. The report's critique of the government's Dispute Resolution Plan stresses its inequities and financial inefficiencies but does not dispute its representation of healing as an individualized process enabled by cash payments. Individual financial compensation, while arguably holding symbolic and psychological value as a form of restitution and acknowledgment of wrongdoing, also reflects how human rights ideology is entwined with market values (Ludi 2006).

Rather than advance an alternate, collectivist model for healing, the Assembly of First Nations report's authors make a compelling case for increased compensation and streamlined, universal payments to individual former students, a significant broadening from the earlier agenda to compensate only victims of physical and sexual abuse. In the settlement that was finally ratified in 2006, the Conservative government agreed to two forms of payment. One was "designed to compensate students who suffered sexual or serious physical abuse or another wrongful act at an Indian Residential School," and required claimants to participate in a separate Independent Assessment Process (IAP). The other was an additional Common Experience Payment (CEP), intended to compensate all former students who could demonstrate attendance at a school listed in the settlement agreement. ${ }^{48}$ Considered against the narrow

\footnotetext{
48 Indian Residential Schools Adjudication Secretariat website: www.iap-pei.ca/former-ancien/ former-ancien-eng.php (accessed 12 July 2016). Compensation payable under the IAP "if abuse is
} 
focus on sexual and physical abuse in Minister Stewart's Statement of Reconciliation a decade before, the inclusion of the universal CEP implies the Canadian state's belated acknowledgment that the Indian residential schools inflicted broader harm beyond individual experiences of abuse. Given this, the Settlement Agreement was unquestionably a moral and political victory for the Assembly of First Nations. How well it addressed the needs of former students of the residential schools is a question I will address in the next section.

The AFN's report offered the settler-state's agents a roadmap for navigating the potentially irreconcilable priorities of cost-saving and humanitarian reputation, and thus harmonizing neoliberal fiscal and moral rationalities (see also Muehlebach 2012). The authors pointed to the extraordinarily high costs of then-ongoing litigation and dispute resolution mechanisms, "the costs of not achieving reconciliation" (linked to discourse describing the financial costs of child abuse), and the cost savings attached to "healing of broken relationships that have undermined the health of the (Canadian) nation over generations." Out-of-court settlements, they argued, "significantly ... offset" the increased cost of compensation through "savings in administration, legal fees, litigation, delay and court costs." Crucially, the report heralds how the revised compensation model will bolster the humanitarian reputation of the settler-state: "Canada and Canadians can be proud [of the proposed model for financial compensation]. It will enhance Canada's reputation as a leader in the world for the respect of human rights ... set an international standard and methodology for dealing with mass violations of human rights, and will finally put behind us, in an honourable way, the most disgraceful, harmful, racist experiment ever conducted in our history." In effect, the authors promise that cash reparations will enable Canadians to put closure to their ongoing reckoning with settlercolonial relations. In this rendering, settler-colonialism is reduced from being a complex history continuous with the present to a singular "experiment."

THE PSYCHIC LIFE OF SETTLER-HUMANITARIAN "HEALING"

In her ethnography of how Canadian humanitarianism affects Inuit, Lisa Stevenson (2014) makes a provocative observation. She notes that Inuit do not experience settler-state interventions aimed at making them live, such as mid-twentieth-century sanatorium-based tuberculosis treatment, and contemporary suicide-prevention programs, as forms of care, but rather as erasures of their identities, cultures, and histories. She analyses this disjuncture as flowing from "the psychic life of biopolitics" in the settler-colonial context:

proven" ranged from $\$ 5,000-275,000$ for sexual abuse, $\$ 11,000-35,000$ for physical abuse, and $\$ 5,000-35,000$ for other wrongful acts. Common Experience Payments averaged \$29,535.

49 The authors cite the 2003 Law Commission of Canada report, "The Economic Costs and Consequences of Child Abuse in Canada." 
"In the psychic lives of both the colonizer and the colonized, the biopolitical commandment to stay alive at all costs is haunted by the desire on the part of the colonist to murder the colonized, and also by the recurring sense the colonized have that what appear to be the most benign public health programs are, in fact, genocidal" (2014: 44). Stevenson's account depicts how Indigenous peoples, in their everyday lives, must grapple with the settler-state's efforts to ameliorate the effects of ongoing dispossession through paternalistic care.

The case of Aboriginal healing shows how settler-humanitarianism shapes such settler-state interventions and also how Indigenous people experience the after-effects. In the process of producing Canadian Aboriginal healing policy, a host of Indigenous and non-Indigenous political actors transmuted "healing" from a collective, social process with anticolonial underpinnings into an individualized, marketized set of biopolitical interventions. We should not be surprised, then, that many residential school survivors, and their families and communities, have experienced the psychic life of these ostensibly benevolent "healing" interventions as ongoing settler-colonial violence that reinforces the political status quo. Here I consider the psychic life and troubling social effects of, first, the regime for implementing the Settlement Agreement (IRSSA), and second, the discourse on historical trauma that has become central to Aboriginal healing in Canada.

Some close observers of the social effects of the Common Experience Payment (that made to all claimants able to prove attendance at an institution recognized by the state as a residential school), found their assessment complicated by the belief that the payments constituted a form of wealth redistribution, benefitting the most marginalized (see also de Costa 2009). One such observer is Leslie Saunders, long-time coordinator of the Meeting Place, a Toronto drop-in center serving homeless and marginally-housed people, many of whom struggle with addictions. They include many residential school survivors, mostly Cree and Anishinaabeg from northern Ontario, who submitted claims under the Settlement Agreement. Commencing her account to me of how participation in this process had affected many regular users of the Meeting Place, Leslie stated, "I think the Aboriginal school money is a positive thing, generally speaking, because it does give some money to people that previously didn't have any money at all." Like many commentators, she applauded the Common Experience Payment as a form of wealth redistribution, and hoped the settlement would redress the racialized socio-economic inequities that characterize contemporary Indigenous-settler relations in Canada.

But this was neither the purpose nor the effect of the compensation. Rather, these payments were embedded in a continuing colonial relationship, and they stamped the recipients with an enduring label of "damaged goods." Leslie made this clear as she elaborated:

However, having said that, it has also spiked the addictions and the suicides, because people are drinking themselves to death with this money. Some of them are so re-traumatized by the process that is required to get that money that it's putting them 
in a terrible mental state, because they're forced to dredge up all these horrible memories that they've worked so hard to try to numb out. ${ }^{50}$ And then after they've been re-traumatized, they're handed this cheque, and so, of course, they do the only thing many of them know how to do, and that's numb out the pain with more drugs and alcohol. So, I really wished that they could have come up with a different process. ${ }^{51}$

Cree and Anishinaabe residential school survivors using the Meeting Place are arguably among the most socially and economically marginalized of claimants. But research with a broader range of survivors confirms that their experiences were not atypical (Reimer 2010a; 2010b). For many, seeking reparations under the Settlement Agreement has been harmful in itself, entrenching their victim status and exacerbating everyday forms of suffering. Many claimants struggled to obtain the required evidence of attendance due to inconsistent church and government record-keeping. Nearly twenty-five thousand endured the distress of having their Common Experience Payment applications dismissed when their claims of suffering were judged illegitimate, and many of them initiated appeals. $^{52}$ Those seeking compensation became entangled in state bureaucratic procedures "in which they carry the burden of proof of their ... damage while experiencing the risk of being delegitimised in legal, welfare, and medical institutional contexts" (Petryna 2002: 216).

Residential school survivors' responses to the Settlement Agreement underscore the inherently anti-political effects of humanitarian interventions, which work to bolster, rather than transform, the established, settler-colonial political order (see Ticktin 2011). Many beneficiaries rejected the assumption, fundamental to the Settlement Agreement, that cash payments would be healing, and instead equated acceptance of them with capitulation to dominant interests (Reimer 2010a). Some concluded that "to settle for individual monetary compensation was misguided and insufficient" (Reimer 2010a: 93-94). Only about one-quarter of recipients described the payment in terms suggesting the possibility for positive transformation, for example, as a meaningful symbol of public recognition of their suffering and admission of government wrongdoing, or an important step towards reconciliation (ibid.).

Infrequent but powerful Indigenous challenges to settler-humanitarianism continued in public events organized by the Truth and Reconciliation Commission. While anthropologists have documented how the workings of the TRC generated significant momentum for "historical trauma" discourse, some exceptional contributions deviated from the TRC's "template" for survivor testimonies, which centered on traumatic experience and suffering,

\footnotetext{
50 More than one-third of survivors surveyed by Aboriginal Healing Foundation researchers said they experienced distressing reactions to the application process: difficult memories, depression, panic, exacerbated addictive behavior, and suicide attempts (Reimer 2010a).

51 Leslie Saunders, oral history shared with the author, 18 Mar. 2010.

52 For statistics describing the CEP and IAP administration, see https://www.aadnc-aandc.gc.ca/ eng/1315320539682/1315320692192 (accessed 14 Aug. 2016).
} 
counterbalanced by a measure of hope (Niezen 2016; see also Molema 2016). Instead, some former students used this forum to condemn the "retraumatizing and dehumanizing" effects of the Independent Assessment Process (IAP), which those seeking compensation for sexual and physical abuse must undergo (Molema 2016: 141). Speaking at an event in Vancouver, residential school survivor and former chief Jillian Harris reported that "a family member had hung himself the day before his IAP adjudication, and that over the course of the IAP, it was 'like the spirit of suicide roared through our community"' (ibid.). In his ethnographic account, Arie Molema further documents how some survivors vociferously disrupted presentations to the Commission by Indigenous and settler political leaders. At one event, during a presentation from British Columbia Premier Christy Clark, a group of Indigenous protestors $^{53}$ brandished a banner proclaiming "We Are Walking Dollars," and threw bags marked with dollar signs onto the stage where Clark stood (ibid.).

The administration of the Settlement Agreement is virtually completed at the time of this writing, but "historical trauma" discourse continues to gain momentum. Canadian health and social work professionals increasingly employ historical trauma as shorthand for Indigenous communities' psychosocial damage, understood as originating in residential school experiences and transmitted inter-generationally within families. In health and child development literatures, a family history of residential school attendance is now an individual "risk factor" that explains a range of complex social phenomena in Indigenous communities, from lack of parenting skills (Ball 2008) to sexual assault (Patterson et al. 2008), Hepatitis C infection (Craib et al. 2009), and suicide (Elias 2012). These theorized relationships are, of course, impossible to prove empirically and can only be demonstrated as correlations.

Invoking "historical trauma" to explain contemporary Indigenous social suffering has problematic, if unintended, corollaries, echoing settlerhumanitarianism. First, historical trauma discourse perpetuates settler-colonial assumptions about the inherent dysfunction of Indigenous families, assumptions that date to the imperial child-rescue movement's universalization of middle-class British values. The persistence of these assumptions among health and social service professionals contributes to the continuing, disproportionate apprehension of Indigenous children by child welfare authorities (Blackstock 2008; de Leeuw et al. 2010; Richardson and Nelson 2007). Second, privileging past experiences of abuse diverts attention from how contemporary (neo)liberal settler-colonialism over-determines Indigenous social suffering. Finally, historical trauma discourse legitimates the indefinite deferral of Indigenous sovereignty over social reproduction, pending attainment of "capacity" (see also Irlbacher-Fox 2009) that is to be built through a host of

\footnotetext{
53 They were part of the group Indian Residential School Critical Analysis and Radical Thoughts (CART) (Molema 2016).
} 
behavioral interventions such as early childhood education and parenting programs, which themselves constitute assimilationist projects.

\section{CONCLUSION}

Indigenous healing has been co-opted by the Canadian state and reworked as settler-humanitarianism, partially displacing the critical, collectivist analyses of earlier Native healing activists. While some Indigenous leaders and professionals have enabled this process, many Indigenous intellectuals continue to advance alternative frameworks in public discourse. These link contemporary Indigenous experiences of social suffering - including interpersonal violence, substance abuse, and suicide - with collective, historical experiences of dispossession and violence, and ongoing racism, marginalization, and violent assaults on the land. Recent writings by Indigenous feminist environmental and sovereignty scholars and activists, for example, offer analyses comparable to those characterizing earlier understandings of Native healing praxis. ${ }^{54}$ Time will tell how such analyses may resist co-option; the case of Aboriginal healing as settler-humanitarianism offers trenchant lessons in this regard.

Meanwhile, "reconciliation" is supplanting "healing" as the keyword for contemporary Canadian settler-humanitarianism. On 5 December 2015, recently elected Prime Minister Justin Trudeau publicly responded to the Truth and Reconciliation Commission's final report. Having delivered brief remarks promising a "national reconciliation framework," Trudeau conspicuously wiped his eyes with a tissue. This widely circulated image was later pronounced by the Huffington Post as one of "The 30 Best Canadian Political Photos of 2015." As I observed in the introduction, the work of the Commission has enabled the Canadian settler-state to redeem itself in humanitarian terms, while failing to reckon with the implications of the residential school system as a settler-humanitarian project that continues to have not only psychosocial effects but also systemic continuities in the present. Trudeau's compelling performance of settler sympathy (including the latest official apology for residential schools) is consistent with his government's continuing disregard for Indigenous sovereignty, exemplified by its support for oil-pipeline construction on Indigenous territory and its failure to allocate adequate resources to redress gross inequities in public services funding on First Nations reserves. As I have argued here, settler expressions of sympathy for Indigenous suffering, and the interventions they justify, serve to simultaneously enable and conceal ongoing Indigenous dispossession. As the current Canadian government moves to develop a national reconciliation framework, critical observers should scrutinize the resulting discourses and interventions for settlerhumanitarianism.

54 See, for example, Women's Earth Alliance 2016. 
Aboriginal Rights Coalition, ed. 2001. Blind Spots: An Examination of the Federal Government's Response to the Report of the Royal Commission on Aboriginal Peoples. Ottawa: Aboriginal Rights Coalition.

Adelson, N. 2000. 'Being alive well': Health and the Politics of Cree Well-Being. Toronto: University of Toronto Press.

Ahmed, S. 2004. Shame before Others: The Cultural Politics of Emotion. New York: Routledge, 101-21.

Akhavan, Payam. 2016. Cultural Genocide: When We Debate Words, We Delay Healing. Globe and Mail, 10 Feb. At: http:/www.theglobeandmail.com/opinion/ cultural-genocide-when-we-debate-words-we-delay-healing/article28681535/ (last accessed 22 Apr. 2017).

Alfred, T. and J. Corntassel. 2005. Being Indigenous: Resurgences against Contemporary Colonialism. Government and Opposition 40, 4: 597-614.

Assembly of First Nations. 1994. Breaking the Silence: An Interpretive Study of Residential School Impact and Healing as Illustrated by the Stories of First Nations Individuals. Ottawa: Assembly of First Nations.

Ball, J. 2008. Promoting Equity and Dignity for Aboriginal Children in Canada. Institute for Research on Public Policy Choices 14, 7: 4-27.

Barnett, M. 2011. Empire of Humanity: A History of Humanitarianism. Ithaca: Cornell University Press.

Berlant, L. 2004. Compassion: The Culture and Politics of an Emotion. New York: Routledge.

Blackburn, C. 2012. Culture Loss and Crumbling Skulls: The Problematic of Injury in Residential School Litigation. Political and Legal Anthropology Review 35, 2: 289-307.

Blackstock, C. 2008. Reconciliation Means not Saying Sorry Twice: Lessons from Child Welfare in Canada. In L. Archibald, M. B. Castellano, and M. DeGagne, eds., From Truth to Reconciliation: Transforming the Legacy of Residential Schools. Ottawa: Aboriginal Healing Foundation, 165-78.

Borrows, J. 2002. Recovering Canada: The Resurgence of Indigenous Law. Toronto: University of Toronto Press.

Briggs, L. 2012. Somebody's Children: The Politics of Transracial and Transnational Adoption. Durham: Duke University Press.

Byrd, J. A. 2011. The Transit of Empire: Indigenous Critiques of Colonialism. Minneapolis: University of Minnesota Press.

Chansonneuve, D. 2005. Reclaiming Connections: Understanding Residential School Trauma among Aboriginal People. Ottawa: Aboriginal Healing Foundation.

Chartrand, L. N., T. E. Logan, and J. D. Daniels. 2006. Métis History and Experience and Residential Schools in Canada. Ottawa: Aboriginal Healing Foundation.

Chen, X. 2003. The Birth of the Child-Victim Citizen. In J. Brodie and L. Trimble, eds., Reinventing Canada: Politics of the 21st Century. Toronto: Prentice Hall, 189-202.

Chrisjohn, R. D. and S. Young. 2006. The Circle Game: Shadows and Substance in the Indian Residential School Experience in Canada. Penticton, British Columbia: Theytus Books.

Cohen, M. G., J. Morrison, and D. Smith. 1995. Dismantling Social Welfare: Chronology of Federal Government Cutbacks, 1985-1995. Canadian Centre for Policy Alternatives Monitor (Nov.): 9-12.

Coulthard, G. S. 2014. Red Skin White Masks: Rejecting the Colonial Politics of Recognition. Minneapolis: University of Minnesota Press. 
Craib, K. J. et al. 2009. Prevalence and Incidence of Hepatitis C Virus Infection among Aboriginal Young People Who Use Drugs: Results from the Cedar Project. Open Medicine 3, 4: 220-27.

Csordas, T. J. 1999. Ritual Healing and the Politics of Identity in Contemporary Navajo Society. American Ethnologist 26, 1: 3-23.

de Costa, R. 2009. Reconciliation and Neoliberalism. Paper presented at the Canadian Political Science Association Annual Conference, Carleton University.

Deer, S. 2009. Decolonizing Rape Law. A Native Feminist Synthesis of Safety and Sovereignty. Wicazo Sa Review 24, 2: 149-67.

de Leeuw, S., M. Greenwood, and E. Cameron. 2010. Deviant Constructions: How Governments Preserve Colonial Narratives of Addictions and Poor Mental Health to Intervene into the Lives of Indigenous Children and Families in Canada. International Journal of Mental Health and Addictions 8: 282-95.

Edmonds, Penelope and A. Johnston. 2016. Empire, Humanitarianism and Violence in the Colonies. Journal of Colonialism and Colonial History 17, 1: 1-19.

Elias, B. 2012. Trauma and Suicide Behaviour Histories among a Canadian Indigenous Population: An Empirical Exploration of the Potential Role of Canada's Residential School System. Social Science and Medicine 74: 1560-69.

Fassin, D. 2012. Humanitarian Reason: A Moral History of the Present. Berkeley: University of California Press.

Fassin, D. and M. Pandolfi. 2010. Contemporary States of Emergency: The Politics of Military and Humanitarian Interventions. New York: Zone Books.

Fassin, D. and R. Rechtman. 2009. The Empire of Trauma: An Inquiry into the Condition of Victimhood. Princeton: Princeton University Press.

Haebich, A. 1992. For Their Own Good: Aborigines and Government in the South West of Western Australia, 1900-1940. Nedlands: University of Western Australia Press.

Haig-Brown, C. 1988. Resistance and Renewal: Surviving the Indian Residential School. Vancouver: Arsenal Pulp Press.

Henderson, J. 2012. Transparency, Spectatorship, Accountability: Indigenous Families in Settler-State "Postdemocracies." English Studies in Canada 38, 3-4: 299-330.

Hillel, M. and S. Swain. 2010. Child, Nation, Race and Empire: Child Rescue Discourse, England, Canada and Australia. Manchester: Manchester University Press.

Howard-Wagner, D. 2010. From Denial to Emergency: Governing Indigenous Communities in Australia. In D. Fassin and M. Pandolfi, eds., Contemporary States of Emergency: The Politics of Military and Humanitarian Interventions. New York: Zone Books, 217-39.

Irlbacher-Fox, S. 2009. Finding Dahshaa: Self-Government, Social Suffering, and Aboriginal Policy in Canada. Vancouver: University of British Columbia Press.

Ivy, M. 1993. Have You Seen Me? Recovering the Inner Child in Late TwentiethCentury America. Social Text 37: 227-52.

Jacob, M. M. 2013. Yakama Rising: Indigenous Cultural Revitalization, Activism, and Healing. Tucson: University of Arizona Press.

Jacobs, M. 2009. White Mother to a Dark Race: Settler Colonialism, Maternalism, and the Removal of Indigenous Children in the American West and Australia, 1880-1940. Lincoln: University of Nebraska Press.

Johnston, B. H. 1988. Indian School Days. Toronto: Key Porter Books.

Kelm, M.-E. 1998. Colonizing Bodies: Aboriginal Health and Healing in British Columbia, 1900-1950. Vancouver: University of British Columbia Press.

Kirmayer, L. J., J. P. Gone, and J. Moses. 2014. Rethinking Historical Trauma. Transcultural Psychiatry 51, 3: 299-319. 
Kirmayer, L. J. and G. G. Valaskakis. 2009. Healing Traditions: The Mental Health of Aboriginal Peoples in Canada. Vancouver: University of British Columbia Press.

Kunitz, S. J. and J. E. Levy. 1997. Dances with Doctors: Navajo Encounters with the Indian Health Service. In A. Cunningham and B. Andrews, eds., Western Medicine as Contested Knowledge. Manchester: Manchester University Press, 94-123.

Lemkin, R. 1944. Axis Rule in Occupied Europe: Laws of Occupation, Analysis of Government, Proposals for Redress. Washington, D.C.: Carnegie Endowment for International Peace.

Lester, A. and F. Dussart. 2014. Colonization and the Origins of Humanitarian Governance: Protecting Aborigines across the Nineteenth-Century British Empire. Cambridge: Cambridge University Press.

Lewellyn, J. J. 2002. Dealing with the Legacy of Native Residential School Abuse in Canada: Litigation, ADR, and Restorative Justice. University of Toronto Law Journal 52, 3: 253-300.

Logan, T. 2008. A Métis Perspective on Truth and Reconciliation. In M. B. Castellano, L. Archibald, and M. DeGagné, eds., From Truth to Reconciliation: Transforming the Legacy of Residential Schools. Ottawa: Aboriginal Healing Foundation, 71-88.

Ludi, R. 2006. The Vectors of Postwar Victim Reparations: Relief, Redress and Memory Politics. Journal of Contemporary History 41, 3: 421-50.

Marshall, W. E. 2011. Potent Mana: Lessons in Power and Healing. Albany: State University of New York Press.

Maxwell, K. 2011. Ojibwe Activism, Harm Reduction and Healing in 1970s Kenora, Ontario: A Micro-History of Canadian Settler Colonialism and Urban Indigenous Resistance. Comparative Programme on Health and Society Lupina Foundation Working Paper Series, 2009-2010. At: http://munkschool.utoronto.ca/cphs/wpcontent/uploads/2012/11/1083MaxwellJuly2011R3.pdf (last accessed 22 Apr. 2017).

Maxwell, K. 2014. Historicizing Historical Trauma Theory: Troubling the TransGenerational Transmission Paradigm. Transcultural Psychiatry 51, 3: 407-35.

Miller, J. R. 1996. Shingwauk's Vision: A History of Native Residential Schools. Toronto: University of Toronto Press.

Million, D. 2013. Therapeutic Nations: Healing in an Age of Indigenous Human Rights. Tucson: University of Arizona Press.

Milloy, J. 1999. A National Crime: The Canadian Government and the Residential School System, 1879-1986. Winnipeg: University of Manitoba Press.

Miskimmin, S. 2007. When Aboriginal Equals “At Risk": The Impact of an Institutional Keyword on Aboriginal Head Start Families. In B. S. McElhinny, ed., Words, Worlds, and Material Girls: Language, Gender, Globalization. New York: Mouton de Gruyter, 107-30.

Molema, A. 2016. Errors of Commission: Canada's Legacy of Indian Residential Schools. PhD diss., University of Toronto.

Mosby, I. 2013. Administering Colonial Science: Nutrition Research and Human Biomedical Experimentation in Aboriginal Communities and Residential Schools, 1942-1952. Social History 46, 91: 145-72.

Muehlebach, A. 2012. The Moral Neoliberal: Welfare and Citizenship in Italy. Chicago: University of Chicago Press.

Nettelbeck, A. et al. 2016. Fragile Settlements: Aboriginal Peoples, Law, and Resistance in South-West Australia and Prairie Canada. Vancouver: University of British Columbia Press.

Niezen, R. 2016. Templates and Exclusions: Victim Centrism in Canada's Truth and Reconciliation Commission on Indian Residential Schools. Journal of the Royal Anthropological Institute 22: 920-38. 
Obomsawin, A. (writer and director). 1993. Kanehsatake: 270 Years of Resistance. Montreal: National Film Board of Canada.

Oldani, M. J. 2009. Uncanny Scripts: Understanding Pharmaceutical Emplotment in the Aboriginal Context. Transcultural Psychiatry 46, 1: 131-56.

Orsini, M. 2010. The Journalist and the Angry White Mob: Reflections from the Field. In L. Simpson and K. L. Ladner, eds., This Is an Honour Song: Twenty Years since the Blockades. Winnipeg: Arbeiter Ring Publishing, 249-60.

Patterson, K. et al. 2008. The Cedar Project: Historical Trauma, Sexual Abuse and HIV Risk among Young Aboriginal People Who Use Injection and Non-Injection Drugs in Two Canadian Cities. Social Science and Medicine 66: 2185-94.

Petryna, A. 2002. Life Exposed: Biological Citizens after Chernobyl. Princeton: Princeton University Press.

Poland, B. et al. 1998. Wealth, Equity and Health Care: A Critique of a "Population Health" Perspective on the Determinants of Health. Social Science and Medicine 46, 7: 785-98.

Povinelli, E. A. 2011. Economies of Abandonment: Social Belonging and Endurance in Late Liberalism. Durham: Duke University Press.

Proulx, C. 2003. Reclaiming Aboriginal Justice, Identity and Community. Saskatoon, Saskatchewan: Purich Publishing.

Regan, P. 2010. Unsettling the Settler Within: Indian Residential Schools, Truth Telling, and Reconciliation in Canada. Vancouver: University of British Columbia Press.

Reimer, G. 2010a. The Indian Residential Schools Settlement Agreement's Common Experience Payment and Healing: A Qualitative Study Exploring Impacts on Recipients. Ottawa: Aboriginal Healing Foundation.

Reimer, G. 2010b. "Mapping Progress" on Community Healing since Implementation of the Settlement Agreement. Ottawa: Aboriginal Healing Foundation.

Richardson, C. and B. Nelson. 2007. A Change of Residence: Government Schools and Foster Homes as Sites of Forced Aboriginal Assimilation. Journal on Innovation and Best Practices in Aboriginal Child Welfare Administration, Research, Policy and Practice 3, 2: 75-83.

Rogers, T. J. and S. Bain. 2016. Genocide and Frontier Violence in Australia. Journal of Genocide Research 18, 1: 83-100.

Royal Commission on Aboriginal Peoples (RCAP). 1993. The Path to Healing: Report of the National Round Table on Aboriginal Health and Social Issues. Ottawa: Ministry of Supply and Services Canada.

Royal Commission on Aboriginal Peoples (RCAP). 1995. Choosing Life: Special Report on Suicide among Aboriginal People. Ottawa: Ministry of Supply and Services.

Rutherford, D. 2009. Sympathy, State Building, and the Experience of Empire. Cultural Anthropology 24, 1: 1-32.

Samson, C. 2009. A Colonial Double-Bind: Social and Historical Contexts of Innu Mental Health. In L. J. Kirmayer and G. G. Valaskakis, eds., Healing Traditions: The Mental Health of Aboriginal Peoples in Canada. Vancouver: University of British Columbia Press, 109-39.

Shewell, H. 2004. Enough to Keep Them Alive: Indian Welfare in Canada, 1873-1965. Toronto: University of Toronto Press.

Short, D. 2008. Reconciliation and Colonial Power: Indigenous Rights in Australia. Aldershot: Ashgate.

Simpson, A. 2014. Mohawk Interruptus: Political Life across the Borders of Settler States. Durham: Duke University Press. 
Simpson, L. 2008. Oshkimaadiziig, the New People. In L. Simpson, ed., Lighting the Eight Fire: The Liberation, Resurgence, and Protection of Indigenous Nations. Winnipeg: Arbeiter Ring Publishing, 13-21.

Stevenson, L. 2014. Life beside Itself: Imagining Care in the Canadian Arctic. Berkeley: University of California Press.

Stoler, A. L. 2010 [2002]. Carnal Knowledge and Imperial Power: Race and the Intimate in Colonial Rule. Berkeley: University of California Press.

Stringer, R. 2007. A Nightmare of the Neocolonial Kind: Politics of Suffering in Howard's Northern Territory Intervention. Borderlands 6, 2. At: http://borderlands. net.au/vol6no2_2007/stringer_intervention.htm (last accessed 22 Apr. 2017).

Sundar, N. 2004. Toward an Anthropology of Culpability. American Ethnologist 31, 2: 145-63.

Survival International. 1999. Canada's Tibet: The Killing of the Innu. At: http://assets.survivalinternational.org/static/files/books/InnuReport.pdf (last accessed 22 Apr. 2017).

Susskind, Y. 2008. Indigenous Women's Anti-Violence Strategies. In S. BahunRadunović and V.G.J. Rajan, eds., Violence and Gender in the Globalised World: The Intimate and the Extimate. Aldershot, UK: Ashgate, 11-24.

Tait, C. L. 2009. Disruptions in Nature, Disruptions in Society: Aboriginal Peoples of Canada and the "Making" of Fetal Alcohol Syndrome. In L. J. Kirmayer and G. G. Valaskakis, eds., Healing Traditions: The Mental Health of Aboriginal Peoples in Canada. Vancouver: University of British Columbia Press, 196-218.

Ticktin, M. I. 2011. Casualties of Care: Immigration and the Politics of Humanitarianism in France. Berkeley: University of California Press.

Truth and Reconciliation Commission of Canada. 2012. They Came for the Children: Canada, Aboriginal Peoples, and Residential Schools. Winnipeg: TRCC.

Truth and Reconciliation Commission of Canada. 2015. Honouring the Truth, Reconciling for the Future: Summary of the Final Report of the Truth and Reconciliation Commission of Canada. Winnipeg: TRCC.

Turner, D. 2006. This Is not a Peace Pipe: Towards a Critical Indigenous Philosophy. Toronto: University of Toronto Press.

Valaskakis, G. G. 2005. Rights and Warriors: Media Memories and Oka. In Indian Country, Essays on Contemporary Native Culture. Waterloo, Ont.: Wilfred Laurier University Press, 13-35.

van Krieken, R. 2004. Rethinking Cultural Genocide: Aboriginal Child Removal and Settler-Colonial State Formation. Oceania 75: 125-51.

van Krieken, R. 2010. Childhood in Australian Sociology and Society. Current Sociology 58, 2: 232-49.

van Krieken, R. 2016. Celebrity, Humanitarianism and Settler-Colonialism: G. A Robinson and the Aborigines of Van Diemen's Land. In L. A. Richey, ed., Celebrity Humanitarianism and North-South Relations: Politics, Place and Power. New York: Routledge, 189-209.

Wagamese, R. 1996. The Terrible Summer: The National Newspaper Award-Winning Writings of Richard Wagamese. Toronto: Warwick Publishing.

Waldram, J. B. 1997. The Way of the Pipe: Aboriginal Spirituality and Symbolic Healing in Canadian Prisons. Peterborough: Broadview Press.

Waldram, J. B., ed. 2008. Aboriginal Healing in Canada: Studies in Therapeutic Meaning and Practice. Ottawa: Aboriginal Healing Foundation.

Watson, I. 2010. In the Northern Territory Intervention: What Is Saved or Rescued and at what Cost? In C. Browne and J. McGill, eds., Violence in France and Australia: Disorder in the Postcolonial Welfare State. Sydney: Sydney University Press. 
Wesley-Esquimaux, C. and M. Smolewski. 2004. Historical Trauma and Aboriginal Healing. Ottawa: Aboriginal Healing Foundation.

Wild, Rex and Pat Anderson. 2007. Ampe Akelyernemane Meke Mekarle, "Little Children Are Sacred." Report of the Northern Territory Board of Inquiry into the Protection of Aboriginal Children from Sexual Abuse. Darwin: Northern Territory Government of Australia.

Wolfe, Patrick. 2006. Settler Colonialism and the Elimination of the Native. Journal of Genocide Research 8, 4: 387-409.

Women's Earth Alliance and Native Youth Sexual Health Network. 2016. Violence on the Land, Violence on Our Bodies: Building an Indigenous Response to Environmental Violence. At: http://landbodydefense.org/uploads/files/Violence $\% 20$ on $\% 20$ the $\%$ 20Land\%20and\%20Body\%20Report\%20and\%20Toolkit\%202016.pdf (last accessed 22 Apr. 2017).

Woolford, A. 2014. Discipline, Territory, and the Colonial Mesh. Indigenous Boarding Schools in the United States and Canada. In A. Woolford, J. Benvenuto, and A. L. Hinton, eds., Colonial Genocide in Indigenous North America. Durham: Duke University Press, 29-48.

\begin{abstract}
Victims of colonial, Indigenous child-removal policies have attracted public expressions of compassion from Indigenous and settler-state political leaders in Canada since the 1990s. This public compassion has fueled legal and political mechanisms, leveraging resources for standardized interventions said to "heal" these victims: cash payments, a truth-telling forum, therapy. These claims to healing provide an entry-point for analyzing how and why the figure of the Indigenous child-victim, past and present, is morally and politically useful for settler-states and their public cultures. I use the formulation of "settlerhumanitarianism" to express how liberal interventions of care and protection, intended to ameliorate Indigenous suffering, align with settler-colonialism's enduring goal of Indigenous elimination (Wolfe 2006). Removal of Indigenous children was integral to the late nineteenth-century formation of the Canadian and Australian settler-states. Missionaries and colonial administrators represented these practices as humanitarian rescue from depraved familial conditions. Settlerhumanitarians have long employed universalizing moral registers, such as "idleness" and "neglect," to compel state interventions into Indigenous families. More recently, "trauma" has emerged as a humanitarian signifier compelling urgent action. These settler-humanitarian registers do political work. Decontextualized representations of Indigenous children as victims negate children as social actors, obscure the particularities of how collective Indigenous suffering flows from settler-colonial dispossession, and oppose children's interests with those of their kin, community, and nation. I analyze how and why Aboriginal healing as settler-humanitarianism has been taken up by many Indigenous leaders alongside settler-state agents, and examine the ongoing social and political effects of the material and discursive interventions it has spawned.
\end{abstract}

Key words: settler-colonialism, humanitarianism, Indigenous peoples, healing, Canada, Australia, children 